\title{
The Scarlet Letter: Embroidering Transcendentalism and Anti-transcendentalism Thread for an Early American World
}

\author{
Ramtin Noor-Tehrani (Noor) Mahini \\ Acalanes High School, Lafayette, California, USA \\ Erin Barth \\ Acalanes High School, Lafayette, California, USA
}

\begin{abstract}
Published in 1850 by Nathaniel Hawthorne, the dark romantic story of The Scarlet Letter was immediately met with success, and Hawthorne was recognized as the first fictional writer to truly represent American perspective and experience. At the time when most novelists focused on portraying the outside world, Hawthorne dwelled deeply in the innermost, hidden emotional and mental psyches of his characters. Despite being acquainted to both famed transcendentalists Ralph Waldo Emerson and Henry David Thoreau and married to the transcendentalist painter Sophia Peabody, Hawthorne was often referred to as antitranscendentalist or dark romantic writer in The Scarlet Letter. Is he also influenced by the transcendentalist movement in his famed novel? Evidence shows that he is more transcendentalist than anti-transcendentalist in The Scarlet Letter.
\end{abstract}

Index Terms - Nathaniel Hawthorne, Scarlet Letter, Hester Prynne, Roger Chillingworth, Arthur Dimmesdale, Pearl, transcendentalism, dark romanticism, anti-transcendentalism

\section{INTRODUCTION}

Riding the wave of heightened nationalism after the second independence war against Great Britain in 1812, Americans began to write their own school textbooks, celebrate the birth of American literature using American scenes and themes, and even establish their own American intellectual, philosophical, and social movements. One of these movements is the American transcendentalism that began in the mid-nineteenth century (1830-1860) in Boston and Concord of New England. This transcendentalist movement was inspired by the publication of Ralph Waldo Emerson's essays, "Nature" in 1836 and "Self-Reliance" in 1841. Stemming from the larger 19th-century European romanticism, New England transcendentalists (Goodman, 2017; Habich and Nowatzki, 2010) reject Calvinism, or the doctrine of predestination practiced by the Puritans, by asserting that human nature is innately good and that truth can be acquired from intuition and nature, not from reason and logic. As such, authority or society-imposed formal institutions such as government and religion may prevent people from using their intuition and cause them to become corrupt. In contrast with transcendentalism, anti-transcendentalism (better known as dark romanticism) is based on the belief that evil and sin are inherent characteristics in human beings. Therefore, optimistic outlook on humanity is naïve because people must struggle to obtain goodness and avoid evil, which can exist even in a physical form in society.

As an American novelist during this interesting time of contrasting intellectual and literary philosophies, Nathaniel Hawthorne weaves both transcendentalism and anti-transcendentalism thread into his immediately successful novel The Scarlet Letter to give readers a chance to evaluate different beliefs and different aspects of the early American life at the New England settlement in the seventeenth century. His story revolves around the life of a young and married Hester Prynne who is punished by her Puritan village to perpetually wear a scarlet letter " $A$ " on her bosom for committing adultery in the absence of her husband, Roger Chillingworth. She gives birth to Pearl, an illegitimate child from her secret affair with the Puritan Reverend Arthur Dimmesdale. At times, Hester and those immediately related to her seem to espouse both or even wrestle between these two contradictory transcendentalist and anti-transcendentalist belief systems, as Hawthorne explores the psychological effects of sin and guilt while simultaneously examining the inner struggle between good and evil through his characters.

\section{BACKGROUND}

Published in 1850 by Nathaniel Hawthorne, the dark romantic story of The Scarlet Letter was immediately met with success. It had made quite an impact on Europe's literary circles, portraying Hawthorne as the first fictional writer to truly represent American perspective and experience. At the time when most novelists focused on the outside world, Hawthorne dwelled deeply in the innermost, hidden emotional and mental psyches of his characters. More than one and a half century later, The Scarlet Letter is now part of the American literary canon, invoking incessant critical reviews on 
its numerous and rich political, religious, scientific, and social themes. The wide range of modern themes on The Scarlet Letter includes: feminism (Daniels, 2005; Wang, 2010); literary symbolism (Lei, 2015); medicine/toxicology (Khan, 1984; Applebaum, 2008); morality (Taylor, 2005; Bloom, 2011); politics (Hunt, 2009; Strong, 2017); sociocultural aspects (Young, 2007; Kumar, 2016); or socio-religious topics such as Christianity (Stuart, no date; Walsh, 2009), Islam (Hariyanti and Nurhayati, 2017), and Puritanism (Gao et al., 2014), etc.

Despite being acquainted to both famed transcendentalists Ralph Waldo Emerson and Henry David Thoreau and married to the transcendentalist painter Sophia Peabody, Hawthorne was often referred to as an anti-transcendentalist or dark romantic writer in The Scarlet Letter because he shows his disagreement with the transcendentalist point of view by describing the presence of sin (Trepanier, 2003) and evil in man, or human tendency toward evil (Manzari, 2012). Is Hawthorne also influenced by the transcendentalist movement? In The Scarlet Letter, is he more anti-transcendentalist or more transcendentalist? The answers are presented in later sections of this article. As Hawthorne selects his weak, pitiful anti-transcendentalist characters as male and depicts good-natured, self-reliant transcendentalist characters as female in his famed novel, perhaps Hawthorne can also be considered an American feminist writer ahead of his time.

\section{TRANSCENDENTALIST ASPECTS OF THE SCARLET LETTER}

The Scarlet Letter contains both transcendentalist and anti-transcendentalist views and ways of life organizing around the central theme of sin. Hester's sin is her adultery with Dimmesdale, which produces her child Pearl. Dimmesdale's sin is his failure to publicly admit his act of adultery with Hester. And Chillingworth's sin is his ruthless torture of Dimmesdale, despite the latter's remorse and sufferings. The basic premises of transcendentalism depicted in the novel include beliefs in self-confidence and self-reliance, in transforming or changing for the better, in individual worth and dignity of manual labor, in innate goodness of people, in the benefits of living close to nature, and in the fact that truth is acquired through intuition, not reason nor logic.

\section{A. Self-confident, Self-reliant, and Dignity of Manual Labor}

In The Scarlet Letter, it is initially determined by the local government that the typical penalty of death for adultery is mercifully reduced due to the fact that Hester's husband may already be "at the bottom of the sea" (deceased) and she can be effectively considered a widow (Hawthorne, 1850, p. 60). As a result, Hester is condemned to stand on the scaffold for three hours at mid-day for public humiliation and wear the scarlet letter A on her chest for the remainder of her life. Although Hester is initially filled with grief and shame for being subject to ridicule and harsh judgment by the townspeople, she chooses to be self-confident and self-reliant. She walks with dignity and displays her own free will, "...he placed his right upon the shoulder of a young woman, whom he thus drew forward; until, on the threshold of the prison-door, she repelled him, by an action marked with natural dignity and force of character, and stepped into the open air, as if by her own free-will." This image shows that when the town beadle tried to force Hester to move forward from the prison door, the dignified and proud Hester rejected his force. She would not let authorities of her society push her around and make her feel weak and vulnerable.

Hester even embroiders the condemned scarlet letter A with luxurious red velvet and gold thread on her chest, “...was that SCARLET LETTER, so fantastically embroidered and illuminated upon her bosom. It had the effect of a spell, taking her out of the ordinary relations with humanity, and inclosing her in a sphere by itself" (Hawthorne, 1850, p. 52). This sentence depicts Hester's strong will to turn her life around, despite her adversity. Instead of letting the scarlet A letter be a symbol of her shame, she selects the finest red cloth and embroiders the letter A with illuminated gold thread to celebrate her unique life, away from the relation with her fellow Puritan society. Perhaps, instead of wearing the typical scarlet letter A as a symbol of shame (Adultery), she proudly wears hers as a token love for Dimmesdale (the initial letter of Arthur, Reverend Dimmesdale's first name) and continues to live a life undisturbed by the harsh judgment of others around her.

To support her infant child Pearl, Hester settles on the outskirts of town, in an abandoned cottage that is next to the seashore and surrounded by the forest to the west (Hawthorne, 1850, p. 78). Alone, she utilizes her skills in needlework to make a living and raise Pearl. She does not leave town, perhaps with a dream to reunite with her lover again someday.

\section{B. Transformation and Innate Human Goodness}

During the early years of her seclusion from society, Hester experiences some transforming or changing in herself, "to the credit of human nature, that, except where its selfishness is brought into play, it loves more readily than it hates. Hatred, by a gradual and quiet process, will even be transformed to love, unless the change be impeded by a continually new irritation of the original feeling of hostility" (Hawthorne, 1850, p. 156). This transformation in Hester, from anger or resentment to love, is a clear display of transcendentalism. She can experience the beauty of love due to good human nature, reflecting transcendentalist ideology. Because of her transformation and her innately good character, Hester never stops helping those who are destitute or sick around her, "Except for that small expenditure in the decoration of her infant, Hester bestowed all her superfluous means in charity, on wretches less miserable than herself, and who not unfrequently insulted the hand that feed them...she employed in making coarse garments for the poor..." (Hawthorne, 1850 , p. 80). It should be noted that her kind-hearted actions are not required or imposed by the law, as she is shunned 
by society and even looked down by people whom she helps. Her "human tenderness," a prominent transcendentalist characteristic, causes the town people to begin to appreciate her charity work; they see the change in the meaning of the fiery letter A on her chest, from "Adultery" to "Able" (Hawthorne, 1850, p. 158). They proudly talk about her to newcomers to town; and the town leaders also start to propose the removing of her sign of punishment, the scarlet letter A, from her chest after only seven years (Hawthorne, 1850, p. 165). Hester's decision to openly acknowledge her sin allows her to keep it from destroying her from the inside, to move on with life, to seek forgiveness, and to flourish as an "able" and caring individual in society - thereby increasing the worth of herself and her societal standing.

\section{Living Close to Nature}

Living on the outskirts of town with Pearl, surrounded by nature - the sea and the woods, Hester also starts to learn about herself, "She had wandered, without rule or guidance, in a moral wilderness...Her intellect and heart had their home, as it were, in desert places...For years past she had looked from this estranged point of view at human institutions... The tendency of her fate and fortune had been to set her free" (Hawthorne, 1850, p. 196). Because of her acquired freedom of thought or of speculation, she can comfortably advise her lover, Reverend Dimmesdale, of the various actions he can take to reduce his guilt and sufferings after she discloses to him that Chillingworth is the assumed entity of her long-lost husband (Hawthorne, 1850, p. 193).

It is in the forest, or nature, where Hester and Dimmesdale reconnect their feelings for each other - and nature responds with a burst of sunshine to celebrate "the bliss of the two spirits! Love..." (Hawthorne, 1850, p. 199). Here in the deep forest, Hester and Dimmesdale can put down their guard, reclaim their deep love toward each other, and agree to escape together to England to begin their life anew, "Do I feel joy again...O Hester, thou art my better angel!...This is already a better life! Why did we not find it sooner?" (Hawthorne, 1850, p. 198). This special moment shows that society-imposed formal institutions such as government and religion collapse in the heart of this couple deeply in love. Seven long years of immense guilt and harsh punishment imposed by society cannot change them and cannot deter them from committing their "sin" again, out of love.

The woods, the seaside, and the nature surrounding Hester and Pearl are also the places where the innocent Pearl is free to express herself, "The truth seems to be, however, that the mother-forest, and these wild things, which it nourished, all recognized a kindred wildness in the human child. And she was gentler here than in the grassy-margained streets of the settlement, or in her mother's cottage," to develop her free-spirit character, and to become independent like her mother, "In the little chaos of Pearl's characters, there might be seen emerging-and could have been, from the very first-the steadfast principles of an unflinching courage-an uncontrollable will-a sturdy price, which might be disciplined into self-respect... which she inherited from her mother must be great indeed..." (Hawthorne, 1850, p. 176). Just like Hester, Pearl is a wonder because she is independent and is not corrupted by institutional rules and laws of society.

\section{Acquiring Truth through Intuition}

In addition, Pearl becomes an observant child full of intuition because she somehow feels and guesses that Dimmesdale is her father without him admitting it or without her mother telling it to her. As a three-month old infant, Pearl instinctively responds to Dimmesdale's voice at the first scaffold scene (Hawthorne, 1850, p. 65). As a three-year old child, she tenderly caresses Dimmesdale's hand when the minister argues on her mother's behalf to keep her (Hawthorne, 1850, p. 112). As a young girl, she asks Dimmesdale to hold her hand and her mother's hand on the scaffold publicly at "noontide" (Hawthorne, 1850, p. 149). At seven years old, she knows that the reason her mother wears a scarlet A on her chest is the same reason as the Reverend Dimmesdale puts his hand over his heart (Hawthorne, 1850, p. 175). She also hopes that Dimmesdale can go back from the meeting in the forest to town with her and her mother "hand in hand, we three together, into the town" (Hawthorne, 1850, p. 208).

\section{ANTI-TRANSCENDENTALIST AsPeCtS OF THE SCARLET LETTER}

As discussed above, in addition to transcendentalist aspects shown primarily in Hester and Pearl, antitranscendentalist elements are also presented in Hawthorne's famed novel. These elements include moral corruption, guilt, hatred, revenge, etc. that are expressed prominently in the characters of Dimmesdale and Chillingworth. These two characters represent aspects of anti-transcendentalism because Dimmesdale is a man of dignity and a religious Puritan minister, and Chillingworth is a rational man of high academic learning. In a way, Puritans are like antitranscendentalists because they believe that humans are born sinners, predestined in the eyes of God.

\section{A. Human Sin and Its Psychological Effects}

Dimmesdale's decision to keep his sin a secret burdens him from the very beginning of the novel, at the first scaffold scene. He is found to have "an air about him, an apprehensive, a startled, a half-frightened look - as of a being who felt himself quite astray and at a loss in the pathway of human existence..." (Hawthorne, 1850, p. 64). Dimmesdale's straying from the path of human existence exemplifies the fear of his own sin, which makes up his dark moral corruption. 
We know that Dimmesdale does not have the courage to admit his sin because he first refuses the older clergyman John Wilson's request to question Hester about the name of her fellow sinner. Later, at the governor's request that Dimmesdale must question Hester, he indirectly conveys to Hester that he does not have the courage to admit his sin, "Take heed how thou deniest to him-who, penchance, hath not the courage to grasp it for himself..." (Hawthorne, 1850, p. 65). In contrast to Hester, who embraces her sin to transform and grow the strength in her character, Reverend Dimmesdale does not have the bravery to face the consequences of his sin, which can be the death penalty under the Puritan rule.

Because Dimmesdale attempts to maintain his composure as a dignified religious leader, his guilt manifests as his health continuously deteriorates, and his self-respect is diminished throughout the novel. As time goes on, he is described as "emaciated; his voice, though still rich and sweet, had a certain melancholy prophecy of decay in it; he was often observed... to put his hand over his heat, with first a flush and then a paleness, indicating pain" (Hawthorne, 1850, p. 117). When Hester first sees Dimmesdale walking in the forest, "He looked haggard and feeble, and betrayed a nerveless despondency in his air" (Hawthorne, 1850, p. 184). He also personally admits to Hester, “... whatever of good capacity there originally was in me, all of God's gifts that were the choicest have become the ministers of spiritual torment. Hester, I am most miserable!" (Hawthorne, 1850, p. 187).

Except for the description of Dimmesdale's guilt and physical/emotional pain, readers learn nothing about the growth of Dimmesdale as a character, unlike Hester. He does not develop any valuable virtue out of his seven remorseful years, and he even admits to Hester that he has plenty of penance but does not achieve penitence (Hawthorne, 1850, p. 188). Despite Hester's complete devotion, Dimmesdale lacks courage, "Think for me, Hester. Thou art strong. Resolve for me" (Hawthorne, 1850, p. 192), honesty, and morality. Hiding behind the protection of his revered priesthood profession and social position as a result of Hester's courage, he even admits that children naturally do not like him (Hawthorne, 1850, p. 203). Young and innocent children have an instinct to recognize naturally good-hearted people. On the other hand, Dimmesdale knows that he has the magic power under the veil of pure and religious devotion to attract young women and virgins in his congregation, perhaps just like with Hester years ago when she was vulnerable at the time of her loneliness (Hawthorne, 1850, p. 215). Perhaps, Dimmesdale truly loves and admires Hester for her strength, because he refuses to take any virgin as his wife when suggested by the townspeople (Hawthorne, 1850, p. 122).

When Dimmesdale agrees to flee town with Hester (thereby committing another sin), he finds himself so liberated of the first burden that he has carried around for seven years that he wants to act out of his normally respectful character, by wanting to use profanity language on children or to flirt with virgin congregationalists of his church. This makes us question if his guilt or remorse for the past seven years is totally sincere. But the weight of his sin is not so easily purged, and he suddenly becomes very weak. After the Election sermon, he reveals his sin to the town and dies.

\section{B. Revenge as Dark Human Emotion and Conviction}

Another character with dominant anti-transcendentalist qualities in the novel is Chillingworth, the assumed entity of Hester's long-lost husband. Chillingworth is a highly learned man, and his sin is of different nature from Dimmesdale and Hester. His sin resides in his persistent vindictiveness toward Dimmesdale, which turns him into a devil because he absolutely refuses to forgive his wife's lover.

On the first day coming back to civilization after being kept by the native "Indians" for two years and upon learning of his wife's betrayal and shame, Chillingworth decides to hide his true entity from the Puritan town because he does not want to be known as the husband of a shameful woman (Hawthorne, 1850, p. 74). He forgives his wife and does not seek vengeance against her because he recognizes that there is a large difference in age between them and because of his deformity (Hawthorne, 1850, p. 71-72). However, he thinks that his wife's secret lover wrongs both of them, perhaps because Hester's lover's unconfessed sin denies her infant a father. Chillingworth then takes on a new mission "to look into the mystery" and find the hiding transgressor as he declares, "It irks me, nevertheless, that the partner of her iniquity should not, at least, stand on the scaffold by her side. But he will be known!" and "I shall seek this man as I have sought truth in books, as I have sought gold in alchemy. There is a sympathy that will make me conscious of him. I shall see him tremble...Sooner or later he must needs be mine!" (Hawthorne, 1850, p. 60-61 and 73).

With his great determination to revenge the hiding transgressor, Hester can feel the darkness in her husband's heart and wonders if her husband is actually like a devil - the Black Man. The anti-transcendentalist characteristic in Chillingworth manifests fully during the seven years after that fateful scaffold day, as Chillingworth relentlessly pursues his revenge, "He had begun an investigation, as he imagined, with the severe and equal integrity of a judge, desirous only of truth...He now dug into the poor clergyman's heart like a miner searching for gold; or rather, like a sexton delving into a grave" (Hawthorne, 1850, p. 125). Even after befriending Dimmesdale, learning about the minister's secret sin, and seeing him collapse under the tremendous guilt, Chillingworth misses no opportunity to mentally torment the poor minister and lengthen his misery, instead of disclosing the minister's sin (Hawthorne, 1850, p. 167).

A good-hearted man would have pardoned a guilt-ridden and repentant person like Dimmesdale, but Chillingworth refuses to do so. That causes the suffering minister to tell Hester, when he finds out about the true entity of Chillingworth: "We are not, Hester, the worst sinners in the world. There is one worse than even the polluted priest! That old man's revenge has been blacker than my sin. He has violated, in cold blood, the sanctity of a human heart. 
Thou and I, Hester, never did so!" (Hawthorne, 1850, p. 191). Dimmesdale is right in noting that relentless revenge is a sin that is worse than any other sin committed by human beings. It causes the pain and sufferings in people to perpetuate in eternity with no ending. Against humanity, revenge can kill the human heart, restricting the ability to love and to forgive.

\section{Devil in Physical Form}

During this time, another anti-transcendental characteristic is seen in Chillingworth - that is he literally becomes a devil in physical form, "At first his expression had been calm, meditative, scholar-like. Now there was something ugly and evil in his face" (Hawthorne, 1850, p. 124). Eventually Chillingworth's evil becomes so invasive that the Puritan village and little Pearl could see the devil of the Black Man in him. Ironically, even Chillingworth notices that he himself has changed from a kind, trustworthy man with "constant if not warm affections" to a devil, as he admits it to Hester: "A mortal man, once with a human heart, has become a fiend for his especial torment!" (Hawthorne, 1850, p. 168-169). Although Chillingworth recognizes his own transformation, he refuses to change for the better and forgive Dimmesdale. As the minister Dimmesdale dies of his weakness and moral corruption, the devil Chillingworth dies within a year of Dimmesdale because he lacks the subject of his vile revenge.

\section{CONCLUSIONS}

As addressed above, there are both transcendentalist and anti-transcendentalist aspects presented in this novel. Although the elements of "sin" and "evil" are pervasive in the story, this book ends on an optimistic note about human nature - highlighting the basis of transcendentalism. It is interesting to find out in the conclusion of this story that although Chillingworth harbors immense hatred and relentlessly pursues torturous revenge toward Reverend Dimmesdale, he has enough empathy and tender feelings for the little innocent Pearl to leave all his great fortune in New England and Great Britain to help the child of his eternal enemy. This generous action from the old and deformed husband that Hester hates and betrays is astounding, considering that Hester's lover Dimmesdale does not even help Hester raise Pearl and leaves Pearl with nothing after this death.

It is also noteworthy to see that the main characters who espouse the anti-transcendentalist point of view all die off in the novel after seven or eight years: Dimmesdale of his own tormenting guilt and Chillingworth of his incessant hatred toward his perceived enemy. Meanwhile, the transcendentalist characters like Hester and Pearl continue to flourish and prosper in their own way. Across the Atlantic Ocean, well-to-do Pearl is described as having a good and possibly aristocratic family life to be able to send her mother valuable gifts with armorial seals to comfort her. And when Hester comes back to the Puritan village that initially shunned and alienated her, she continues to comfort and counsel the suffering people around her, until the day she dies and is buried alongside with her lover. While Chillingworth and Dimmesdale display human possibilities of committing evil acts and self-destruction, Hester and Pearl represent the human capability for healing, surviving, and thriving. Perhaps Hawthorne is suggesting to future generations that although human nature is both good or bad, goodness will always prevail.

\section{REFERENCES}

[1] Applebaum, L. (2008). The Scarlet Letter: Deadly nightshake, dogwood, and henbane. The Herbarist 74, 30-33.

[2] Bloom, H. (2011). Bloom's Guides: The Scarlet Letter - New Edition. New York: Infobase Publishing.

[3] Gao, J. et al. (2014). The influence of Puritanism on the sin and punishment in The Scarlet Letter. Research on Humanities and Social Sciences 4(27), 175-179.

[4] Goodman, R. (2017). Transcendentalism. The Stanford Encyclopedia of Philosophy (Summer 2017 Edition), Edward N. Zalta (ed.) https://plato.stanford.edu/archives/sum2107/entries/transcendentalism (Accessed 11/30/2017).

[5] Habich, R. and R. Nowatzki (2010). Research Guide to American literature: Romanticism and Transcendentalism 1820-1865. New York: Facts on File, Inc.

[6] Hariyanti, T. and D. Nurhayati. (2017). Pearl in Hawthorne's the Scarlet Letter: a socio-religious perspective. Arab World English Journal 1(1), 65-78.

[7] Hawthorne, N. (1850). The Scarlet Letter. Illinois, USA: Perma-Bound International. Published in 1988.

[8] Hunt, C. (2009). The persistence of theocracy: Hawthorne's The Scarlet Letter. Perspectives on Political Science 38(1), $25-32$.

[9] Khan, J. (1984). Atropine poisoning in Hawthorne's The Scarlet Letter. The New England Journal of Medicine 311 (6), 414416.

[10] Kumar, R. (2016). Socio-cultural patterns of privacy and interconnections in Hawthorne's The Scarlet Letter. International Journal of Multidisciplinary Approach and Studies 3(5), 101-112.

[11] Lei, N. (2015). A brief study on the symbolic meaning of the main characters' names in The Scarlet Letter. Theory and Practice in Language Studies 5(10), 2164-2168.

[12] Manzari, A. (2012). Contextual American transcendentalism. Theory and Practice in Language Studies 2(9), $1792-1801$.

[13] Strong, T. (2017). Hawthorne, the politics of sin, and Puritanism. Telos. Spring 178, 121-142.

[14] Stuart, J.W. (no date). Christian Imagery in Hawthorne's The Scarlet Letter. http://www.hawthorneinsalem.org/ScholarsForum/MMD1824.html (accessed 12/30/2017).

[15] Taylor, C. (2005). Moralism and morally accountable beings. Journal of Applied Philosophy 22(2), 153-160.

[16] Trepanier, L. (2003). The need for renewal: Nathaniel Hawthorne's conservatism. Modern Age 45(4), 315-323.

[17] Wang, Y. (2010). A representative of the new female image - Analyzing Hester Prynne's feminist consciousness in The Scarlet 
Letter. Journal of Language Teaching and Research 1(6), 893-897.

[18] Walsh, C.M. (2009). Nathaniel Hawthorne with His Biblical Context. PhD Dissertation. University of Nevada. https://digitalscholarship.unlv.edu/thesesdissertations/1115/ (Accessed 12/30/2017).

[19] Young, R.V. (2007). Individual and Community in The Scarlet Letter. The Intercollegiate Review, 32-40.

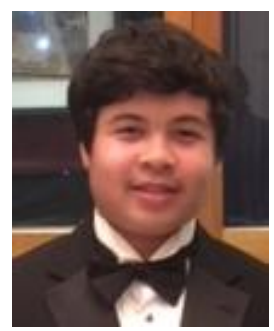

Noor (meaning Light) Mahini (full name Ramtin Noor-Tehrani Mahini) was born in October 2001 in Berkeley, CA and is currently a junior at Acalanes High School in Lafayette, CA, USA. Noor has been a highachieving student since middle school, excelling in computers, math, and science. He applies his deep critical thinking in most things he does, especially in writing English essays and in conducting a small climate change research project awarded by the Acalanes Parents Club at school. Raised by first-generation immigrant parents (Ramtin T. and Xuannga, who received $\mathrm{PhD} /$ engineering and $\mathrm{MPH} /$ toxicology, respectively, from University of California, Berkeley), Noor's life purpose is to develop a morally respectable character and to become a responsible, devoted citizen to his people/his country and an advocate for human rights.

Noor is a third degree black belt in Tae Kwon Do and enjoys tennis and golf. He is currently doing longterm volunteer work at Youth Tennis Advantage (YTA) to assist children with academics and tennis. Although he loves piano, he is better in viola as he has been playing viola in school orchestras for 5 years. Regardless of what his future college major and career aspiration may be, his life goal is to help make this world a better place.

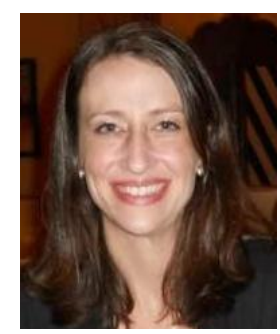

Erin Barth received her Bachelor's and Master's degrees as well as her teaching credential from University of California, Davis, USA.

She is currently an English teacher at Acalanes High School in Lafayette, CA. She lives with her husband Ben, daughter Madeline, and their two Boxers Fletcher and Calvin.

Mrs. Barth enjoys going the extra mile for her students. She is always willing to spend time after school in order to help her students improve their writing skills and develop their appreciation for literature. 